\title{
A questão da propriedade dos bens na Doutrina Social da Igreja
}

\section{The question of the property of goods in the Social Doctrine of the Church}

\author{
Paulo Fernando Andrade* \\ PUC-Rio
}

Recebido em: 02/03/2021. Aceito em: 12/03/2021.

Resumo: A questão da Propriedade dos Bens sempre possuiu um lugar importante no Ensino Social da Igreja, da Patrística aos nossos dias. Na moderna Doutrina Social da Igreja, de Leão XIII a Francisco este tema possui um rico desenvolvimento que, de um lado se mantêm fiel ao princípio da Destinação Universal dos Bens que se encontra no ensinamento dos Padres da Igreja desde os primeiros séculos do Cristianismo e, de outro, acrescenta novas dimensões a este princípio, como a dimensão ecológica e intergeracional, isto é, o dever da atual geração de garantir que as futuras gerações possam ter pleno acesso aos bens criados por Deus, de modo a garantir a vida e a satisfação das necessidades de todos os humanos, de hoje e de amanhã. Neste artigo acompanharemos o desenvolvimento da Questão da Propriedade dos Bens, na Doutrina Social da Igreja, desde seus fundamentos na patrística e na escolástica, dando especial ênfase ao Magistério do Papa Francisco.

Palavras-chave: Doutrina Social da Igreja. Destinação Universal dos Bens. Direito de Propriedade.
Abstract: The question of the property of the goods has always had an important place in the Social Teaching of the Church, from Patristics to the present day. In the modern Social Doctrine of the Church, from Leo XIII to Francis, this theme has a rich development that, on the one hand, remains faithful to the principle of the Universal Destination of Goods that is found in the teaching of the Fathers of the Church since the first centuries of Christianity and, on the other, it adds new dimensions to this principle, such as the ecological and intergenerational dimen- sion, that is, the duty of the current generation to ensure that future generations
* Doutor em Teologia (Pontifícia Universidade Gregoriana de Roma, Roma, Itália, 1989); Graduado em Engenharia Mecânica Ênfase Nuclear (Pontifícia Universidade Católica do Rio de Janeiro, PUC-RJ, Rio de Janeiro-RJ, 1981).
E-mail: paulof@puc-rio.br 
can have full access to the goods created by God, in order to guarantee life and satisfaction of the needs of all humans, today and tomorrow. In this article, we will follow the development of the Question of Property Ownership, in the Social Doctrine of the Church, from its foundations in patristics and scholasticism, with special emphasis on the Magisterium of Pope Francis.

Keywords: Church Social Doctrine. Universal Destination of Goods. Property right.

\section{Introdução}

O Ensino Social da Igreja é parte de seu Magistério desde o início do Cristianismo. Já nos Padres da Igreja encontramos uma profunda Teologia Social que se enriquece na Escolástica e que na época moderna se torna um corpo magisterial orgânico, consusbstancializado em um conjunto de Documentos Pontifícios que desde a Rerum Novarum de Leão XIII (1891) à Fratelli Tutti do Papa Francisco (2020) formam a chamada moderna Doutrina Social da Igreja. Neste rico Magistério encontramos elementos permanentes que, embora possam receber ênfases diferentes segundo cada época e segundo diferentes paradigmas, constituem o núcleo mais profundo da Tradição Evangélica, das Escrituras aos nossos dias, relativa às questões sociais e econômicas. Refletiremos aqui sobre a questão da propriedade dos bens terrenos, sua pertinência e seus limites segundo o Ensinamento Social da Igreja, com especial ênfase no Magistério do Papa Francisco.

\section{Os princípios da moral sócio econômica dos Padres da lgreja e o direito de propriedade}

Em quase todos os Padres da Igreja, de todo o período patrístico, seja no Ocidente, seja no Oriente, encontramos um conjunto substantivo de escritos que abordam a questão social e econômica. Em todos estes escritos dois princípios se apresentam como basilares: a Destinação Universal dos Bens e a afirmação de que o supérfluo por direito é do Pobre.

Destinação Universal dos Bens. Afirmam os Padres da Igreja que Deus criou o mundo e todas as coisas para satisfazer a necessidade de todos e não apenas de alguns. Este é o princípio mais fundamental da Moral Sócio Econômica Patrística.

O supérfluo por direito é do Pobre. Os Padres da Igreja admitem a legitimidade ético-jurídica da propriedade privada, desde que 
subordinada ao princípio da Destinação Universal dos Bens. Os ricos não possuem de modo absoluto suas propriedades. Somos na verdade não proprietários, mas sim administradores dos bens dos quais temos a posse e que devem ser usados para satisfazer as necessidades de todos. Deste modo aquilo de que temos a posse, mas que excede às nossas necessidades é por direito daquele que necessita. O que damos aos pobres não constitui um ato de generosidade, mas de justiça, damos aos pobres o que é deles por direito.

Um dos escritos patrísticos mais significativos sobre a riqueza onde são explicitados estes dois princípios se encontra em Basílio Magno, em sua Homilia sobre Lucas $12,16-21^{1}$

O que faço de errado, diz ele, guardando o que é meu?

Dize-me, de que modo é teu? Donde tiraste, tomando-o para teu sustento? É como alguém que, indo ao teatro, se apoderasse do espetáculo e quisesse excluir os que entrassem depois, pretendendo ser só seu aquilo que é comum a todos os que se apresentam, conforme lhes parece bem. Assim são os ricos. Pois, apoderando-se primeiro do que é de todos, tudo tomam para si por uma falsa ideia. Se cada um tirasse para si o que lhe é necessário e entregasse ao Indigente o que sobra, ninguém seria rico, ninguém pobre. Não saíste nu do útero e não retornarás nu para a terra $(J o ́ 1,21)$ ? Os bens que possuis, de onde vêm? Se dizes que provêm do acaso, és ímpio, não reconhecendo o Criador e não dando graças ao doador. Se, ao invés, admites que são de Deus, dize-me por que os recebeste. É talvez injusto Deus, que nos distribui os meios de subsistência de modo desigual? Por que tu és rico e aquele é pobre? Certamente para que tu pudesses receber a recompensa da bondade da fiel administração e aquele pudesse conseguir o magnifico prêmio da paciência. E tu, e quanto procuras abarcar tudo nos insaciáveis ventres da avareza, julgas não fazer injustiça a ninguém, privando tanta gente do necessário? Quem é o avarento? Aquele que não se contenta com aquilo que lhe é suficiente. Quem é o ladrão? Quem tira aquilo que é de outro. Não és avaro? Não és ladrão, tu que fazes tua a propriedade que recebeste para administrar? Quem espolia alguém que está vestido é tido como ladrão; e quem, podendo fazê-lo, não reveste quem está nu merecerá outro nome? O pão que tu reténs pertence ao faminto, o manto que guardas no armário é de quem está nu; os sapatos que apodrecem em tua casa pertencem ao descalço; o dinheiro que tens enterrado é 
do necessitado. Porque tantos são aqueles aos quais fazes injustiças, quantos aqueles que poderias socorrer.

Reter o que excede minhas necessidades e faz falta para suprir as necessidades do outro não é apenas uma falta moral, como a avareza, mas um ato de injustiça, um roubo. Por reter para mim aquilo que por direito é do outro, torno-me um ladrão. Embora eu tenha a posse deste bem, ele não me pertence, e sim ao necessitado. Deste modo a propriedade privada não é um princípio absoluto, não posso dispor dos bens dos quais tenho posse, segundo meus desígnios. Devo colocá-los a serviço das necessidades de todos, independente da origem desta posse, se herança, se meu trabalho, se sorte, comércio, ou outra coisa. Em última instância todos os bens foram criados por Deus para satisfazer às necessidades de todos. Se por algum motivo tenho a posse de mais do que necessito para viver e o que tenho falta ao outro, sou obrigado, por dever de justiça, a repartir o que possuo em excesso, como um bom administrador dos bens que a mim foram confiados, de tal modo que o outro possa ter também o necessário à vida.

Assim, mesmo que os Padres admitam a legitimidade da propriedade privada, esta é sempre relativa e expressamente subordinada ao princípio geral e basilar da Destinação Universal dos Bens. Um outro escrito de Basílio também aborda de maneira veemente estes dois princípios. Trata-se da Homilia sobre o jovem rico (Mt 19,16ss), conhecida também como Homilia contra os Ricos ${ }^{2}$. Neste texto ele afirma que o jovem rico não podia dizer que cumpria os mandamentos por ser possuidor de tantos bens e não haver socorrido com suas posses aos necessitados. Uma interpretação muita próxima à que se encontra no Evangelho Apócrifo dos Hebreus, que narra este episódio do seguinte modo, conforme atesta Pseudo Origines Latino em seu Comentário sobre Mateus 15,14ss, onde escreve:

Está escrito em certo evangelho, chamado segundo Os Hebreus (se é que se possa admiti-lo, não como autoridade, senão para esclarecimento da questão proposta): Disse-lhe o outro dos dois ricos: Que tenho de fazer do bom para poder viver? Disse-lhe [Jesus]: Cumpre a Lei e os Profetas. Responde-o o rico: Já o venho fazendo. Disse-lhe: Vai, vende tudo o que é teu, distribui entre os pobres, e vem, segue-me. Mas o rico começou a balançar a cabeça, e não lhe agradou o conselho. Disse-o o

2 RESTITUTO SIERRA BRAVO. Doctrina Social y Economica de los Padres de la Iglesia. Coleccion General de Documentos Y Textos. Madri: COMPI, 1967. p. 178-191. 
Senhor: Como te atreves a dizer: Tenho observado a Lei e os Profetas? Está escrito na Lei: Amarás a teu próximo como a ti mesmo. E existem muitos irmãos teus, filhos de Abraão, que estão vestidos de trapos e morrem de fome, enquanto sua casa está cheia de bens sem que saia nada dela para socorrê-los ${ }^{3}$.

Muitos outros textos patrísticos poderiam aqui ser citados ${ }^{4}$. Apenas para atestarmos como esta doutrina era comum ao Ocidente e ao Oriente faremos referência, a título de exemplo, a Santo Ambrósio e sua Homilia sobre As Vinhas de Nabot ${ }^{5}$. Neste magnífico texto Santo Ambrósio afirma dirigindo-se ao rico:

Não dás ao pobre aquilo que é seu, senão que devolves a ele o que é dele. Pois o que é comum e foi dado para o uso de todos usurpas para ti somente. A terra é de todos, não só dos ricos; porém são muito menos os que gozam dela do que os que dela gozam. Pagas, pois, um débito, não dás gratuitamente o que julgas que não deve: 'Prestas atenção, sem enojar-se, ao pobre, e 'paga tuas dividas e responde-lhe a saudação com afabilidade' (Eclesiástico 4,8).

\section{A questão da propriedade em São Tomás de Aquino}

A teologia de São Tomás se tornará central no paradigma teológico-magisterial desenvolvido por Leão XIII ${ }^{7}$ e, notadamente no início da moderna Doutrina Social da Igreja, a teologia de São Tomás relativa à propriedade privada terá grande relevo.

3 OTERO, A. de Santos. Los Evangelios Apocrifos. Edición crítica y bilíngue. 6. ed. Madri: BAC, 1988. p. 42-43. Alguns autores consideram ser este um fragmento do chamado Evangelho dos Nazarenos, cf. CRAVERI, M. (org.). I Vangeli Apocrifi. 5. ed. Torino: Einaudi, 1969. p. 269.

4 MARA, Maria Grazia. Annuncio evangelico e istanze sociali nel IV secolo. Augustinianum, vol. 17, n. 1, p. 7-24.

5 AMBROGIO. La storia di Naboth. Introduzione, commento, edizione critica, traduzione a cura di Maria Grazia Mara. L'Aquila: Japadre, 1975. O texto encontra-se também em Restituto Sierra Bravo, op. cit., p. 660-682.

6 RESTITUTO SIERRA BRAVO, 1967, p. 677-678.

7 HOLLAND, J. Modern Catholic Social Teaching. The Popes confront the industrial age 1740-1958. New York: Paulist Press, 2003. Também de forma mais extensa desenvolvi o tema dos sucessivos paradigmas na Doutrina Social da Igreja de Leão XIII a Francisco em ANDRADE, P. Um novo paradigma na Doutrina Social da Igreja, REB vol. 79, n. 314 (Set./Dez. 2019), p. 615-636. 
São Tomás trata da legitimidade da propriedade nos dois primeiros artigos da Questão 66 da IIa-IIae $e^{8}$. Trata-se da Questão intitulada " $D o$ Furto e do Roubo", onde primeiro se discute "se é natural ao homem a posse dos bens externos" e em seguida "se é lícito a alguém possuir uma coisa como própria". São Tomás citando as Escrituras e fazendo referência a Aristóteles conclui que:

Uma coisa externa pode ser considerada à dupla luz. Na sua natureza, que não depende do poder humano, mas só do divino, a cuja vontade tudo obedece. E no uso mesmo a que ela serve. E, deste segundo modo, o homem tem naturalmente o domínio sobre as coisas externas; pois, pela sua razão e pela sua vontade, pode usar das coisas externas para a sua utilidade, como se para si fossem feitas; pois, sempre o mais imperfeito é para o mais perfeito, como já estabelecemos. E, por esta razão, o Filósofo prova que a posse das coisas externas é natural ao homem. Pois, esse domínio natural sobre todas as criaturas, que cabe ao homem por ser dotado de razão, que é uma imagem de Deus, manifesta-se na criação mesma dele, conforme a Escritura: Façamos o homem à nossa imagem e semelhança, o qual presida aos peixes do mar, etc.

Resolvida a questão admitindo-se a legitimidade da propriedade por parte da humanidade das coisas criadas no que tange a seu uso, conforme a sua utilidade, São Tomás se debruça sobre a licitude de alguém possuir algo como próprio, e não como comum. São Tomás admite a licitude da propriedade privada utilizando um argumento de conveniência:

Relativamente às coisas exteriores tem o homem dois poderes. Um éo de administrá-las e distribui-las. E, quanto a esse, é-lhe lícito possuir coisas como próprias. O que é mesmo necessário à vida humana por três razões. - A primeira é que cada um é mais solícito em administrar o que a si só lhe pertence, do que o comum a todos ou a muitos. Porque, neste caso, cada qual, fugindo do trabalho, abandona a outrem o pertencente ao bem comum, como se dá quando há muitos criados. - Segundo, porque as coisas humanas são melhores tratadas, se cada um emprega os seus cuidados em administrar uma coisa determinada; pois, se ao contrário, cada qual administrasse indeterminadamente qualquer coisa, haveria confusão. - Terceiro, porque, assim, cada um, estando contente com o seu, melhor se conserva a paz entre os homens. Por isso, vemos nascerem constantemente rixas entre os possuidores de uma coisa em comum e indivisamente.

8 Disponível em: https://sumateologica.files.wordpress.com/2017/04/suma-teolc3b3gica. pdf. Acesso em: 18 fev. 2021. 
E em seguida acrescenta:

O outro poder que tem o homem sobre as coisas exteriores é o uso delas. E, quanto a este, o homem não deve ter as coisas exteriores como próprias, mas, como comuns, de modo que cada um as comunique facilmente aos outros, quando delas tiverem necessidade. Por isso diz o Apóstolo: Manda aos ricos deste mundo que deem, que repartam francamente.

E ainda:

A comunidade das coisas é atribuída ao direito natural: não que o direito natural dite que tudo deve ser possuído em comum e nada como próprio. Mas que o possuir em separado não se funda no direito natural, mas antes, na convenção humana, que respeita o direito positivo, como já dissemos. Por onde, a propriedade dos bens exteriores não é contra o direito natural, mas é um acréscimo feito a este por expediente da razão humana.

Ao responder as objeções feitas à licitude da propriedade privada São Tomás cita a homilia de São Basílio já tratada aqui para afirmar que:

Quem, chegando primeiro ao espetáculo, preparasse a entrada para os outros, não agiria ilicitamente, mas, assim age, impedindo-os de entrar. E semelhantemente, não age ilicitamente o rico, apropriando-se de uma coisa exterior que a princípio era comum, contanto que a comunique aos outros; peca, porém, se indebitamente os impede de usar dela. Por isso Basílio, no mesmo lugar, diz: Porque vives tu na abundância enquanto o outro mendiga, senão para ganhares tu os méritos de dispender bem e ser ele coroado com o prêmio da paciência?

Claramente São Tomás subordina a licitude da propriedade privada ao princípio primeiro da Destinação Universal dos Bens que pertence aos desígnios de Deus para a Sua Criação e, por conseguinte, à Lei Natural. Conforme o seu argumento de conveniência (que não se constitui a partir de nenhuma citação bíblica ou patrística), quando a propriedade privada permitir que a humanidade possa aproveitar melhor das coisas criadas para satisfazer a necessidade de todos, esta é licita, por facilitar que se atinja o fim natural das coisas querido por Deus (a satisfação das necessidades humanas). Quando, ao contrário, esta se constituir em um impedimento para que todos possam ter suas necessidades atendidas, esta se torna ilícita, conforme suas palavras, citando Santo Ambrósio: "Quando Ambrósio diz - Ninguém chame próprio ao que é comum refere-se ao uso da propriedade. Por isso acrescenta: Todo o excedente às nossas necessidades, por violência é que o obtivemos". 


\section{A questão da propriedade privada na Rerum Novarum e na Quadragesimo Anno}

Na Encíclica Rerum Novarum de $1891^{9}$, que inaugura a Doutrina Social da Igreja na época Moderna ${ }^{10}$, Leão XIII aborda diretamente a questão da propriedade privada, em um contexto no qual, de um lado, diversas correntes socialistas contestavam a sua legitimidade, e de outro, as correntes liberais advogavam ser a propriedade privada um direito absoluto. Leão XIII defende a legitimidade da propriedade privada, entendida como sendo de direito natural, pois é a forma que a razão humana encontrou para organizar a vida em comum de tal modo que todos possam usufruir dos bens criados e satisfazer suas necessidades, conforme os desígnios de Deus. A propriedade privada é fruto do trabalho de cada um, a consubstanciação do salário recebido em bens duráveis, que possam satisfazer as necessidades do trabalhador e sua família, segundo o esforço e os objetivos de cada um, livremente, independente da vontade coletiva ou do Estado (RN 4 e 5). Aqui encontra-se um argumento novo a favor da legitimidade da propriedade privada não utilizado anteriormente por São Tomás: a propriedade privada como fonte e garantia de liberdade do indivíduo e sua família frente ao Estado ${ }^{11}$ :

A natureza não impõe somente ao pai de família o dever sagrado de alimentar e sustentar seus filhos; vai mais longe. Como os filhos refletem a fisionomia de seu pai e são uma espécie de prolongamento da sua pessoa, a natureza inspira-lhe o cuidado do seu futuro e a criação dum patrimônio que os ajude a defender-se, na perigosa jornada da vida, contra todas as surpresas da má fortuna. Mas, esse patrimônio poderá ele criá-lo sem a aquisição e a posse de bens permanentes e produtivos que possam transmitir-lhes por via de herança?

Assim como a sociedade civil, a familia, conforme atrás dissemos, é uma sociedade propriamente dita, com a sua autoridade e o seu governo paterno, é por isso que sempre indubitavelmente na esfera que lhe determina o seu fim imediato, ela goza, para a escolha e uso de tudo o

9 Disponível em: http://www.vatican.va/content/leo-xiii/pt/encyclicals/documents/hf_I-xiii_enc_15051891_rerum-novarum.html. Acesso em: 20 fev. 2021.

10 SHANNON, Thomas. Rerum Novarum em Kenneth Himes (ed.). Modern Catholic Social Teaching. Commentaries and Interpretations. 2nd Edition. Washington DC: Georgetown University Press, 2018. p. 133-157.

11 CURRAN, Charles. Catholic Social Teachimg. A Historical, Theological and Ethical Analysis. 1891-Present. Washington DC: Georgetown University Press, 2002. p. 173214. 
que exigem a sua conservação e o exercício duma justa independência, de direitos pelo menos iguais aos da sociedade civil. Pelo menos iguais, dizemos Nós, porque a sociedade doméstica tem sobre a sociedade civil uma prioridade lógica e uma prioridade real, de que participam necessariamente os seus direitos e os seus deveres. E se os indivíduos e as familias, entrando na sociedade, nela achassem, em vez de apoio, um obstáculo, em vez de proteção, uma diminuição dos seus direitos, dentro em pouco a sociedade seria mais para se evitar do que para se procurar. (RN 6).

O princípio patrístico de que o supérfluo por direito é do necessitado é reconhecido por Leão XIII:

A propriedade particular, já o dissemos mais acima, é de direito natural para o homem: o exercício deste direito é coisa não só permitida, sobretudo a quem vive em sociedade, mas ainda absolutamente necessária. Agora, se se pergunta em que é necessário fazer consistir o uso dos bens, a Igreja responderá sem hesitação: "A esse respeito o homem não deve ter as coisas exteriores por particulares, mas sim por comuns, de tal sorte que facilmente dê parte delas aos outros nas suas necessidades. É por isso que o Apóstolo disse: "Ordena aos ricos do século... dar facilmente, comunicar as suas riquezas».

Ninguém certamente é obrigado a aliviar o próximo privando-se do seu necessário ou do de sua família; nem mesmo a nada suprimir do que as conveniências ou decência impõem à sua pessoa: «Ninguém com efeito deve viver contrariamente às conveniências». Mas, desde que haja suficientemente satisfeito à necessidade e ao decoro, é um dever lançar o supérfluo no seio dos pobres: "Do supérfluo dai esmolas». É um dever, não de estrita justiça, exceto nos casos de extrema necessidade, mas de caridade cristã, um dever, por consequência, cujo cumprimento não se pode conseguir pelas vias da justiça humana. (RN 12).

O Papa Pio XI na Encíclica Quadragesimo Anno (1931) ${ }^{12}$, retoma de modo destacado a questão da legitimidade da propriedade privada, colocando, entretanto, forte ênfase na dimensão, não apenas individual da propriedade, mas também em sua dimensão social ${ }^{13}$ :

12 Disponível em: http://www.vatican.va/content/pius-xi/pt/encyclicals/documents/hf_p-xi_enc_19310515_quadragesimo-anno.html. Acesso em: 20 fev. 2021.

13 HINZE, Christine. Quadragesimo Anno em Kenneth Himes (ed.), Modern Catholic Social Teaching. Commentaries and Interpretations. 2nd Edition. Washington DC: Georgetown University Press, 2018. p. 158-182. 
Primeiramente tenha-se por certo, que nem Leão XIII, nem os teólogos, que ensinaram seguindo a doutrina e direção da Igreja, negaram jamais ou puseram em dúvida a dupla espécie de domínio, que chamam individual e social, segundo diz respeito ou aos particulares ou ao bem comum; pelo contrário foram unânimes em afirmar que a natureza ou o próprio Criador deram ao homem o direito do domínio particular, não só para que ele possa prover às necessidades próprias e da família, mas para que sirvam verdadeiramente ao seu fim os bens destinados pelo Criador a toda a família humana: ora nada disto se pode obter, se não se observa uma ordem certa e bem determinada.

Deve, portanto, evitar-se cuidadosamente um duplo escolho, em que se pode cair. Pois como o negar ou cercear o direito de propriedade social e pública precipita no chamado «individualismo» ou dele muito aproxima, assim também rejeitar ou atenuar o direito de propriedade privada ou individual leva rapidamente ao «coletivismo» ou pelo menos à necessidade de admitir-lhe os princípios. (QA 1).

O caráter privado de uma propriedade não anula sua dimensão social, e assim para Pio XI, cabe ao Estado regular o uso que se pode fazer legitimamente da propriedade:

Efetivamente, que deva o homem atender não só ao próprio interesse, mas também ao bem comum, deduz-se da própria índole, a um tempo individual e social, do domínio, a que nos referimos. Definir porém estes deveres nos seus pormenores e segundo as circunstâncias, compete, já que a lei natural de ordinário o não faz, aos que estão à frente do Estado. E assim a autoridade pública, iluminada sempre pela luz natural e divina, e pondo os olhos só no que exige o bem comum, pode decretar mais minuciosamente o que aos proprietários seja lícito ou ilícito no uso de seus bens. (QA 1).

Entretanto, apesar da ênfase no caráter social de toda propriedade reconhecendo a primazia da destinação Universal dos Bens (aqui chamado de Bem Comum), Pio XI faz nesta Encíclica uma afirmação que não se ancora nem na Tradição anterior, nem encontrará recepção na Tradição posterior: a de que o abuso relativo ao uso da propriedade não possa levar a perda ou mesmo extinção do direito da propriedade:

E a fim de pôr termo às controvérsias, que acerca do domínio e deveres a ele inerentes começaram a agitar-se, note-se em primeiro lugar o fundamento assente por Leão XIII, de que o direito de propriedade é distinto do seu uso. Com efeito, a chamada justiça comutativa obriga a conservar inviolável a divisão dos bens e a não invadir o direito alheio 
excedendo os limites do próprio domínio; que porém os proprietários não usem do que é seu, senão honestamente, é da alçada não da justiça, mas de outras virtudes, cujo cumprimento «não pode urgir-se por vias jurídicas». Pelo que sem razão afirmam alguns, que o domínio e o seu honesto uso são uma e a mesma coisa; e muito mais ainda é alheio à verdade dizer, que se extingue ou se perde o direito de propriedade com o não uso ou abuso dele. (QA 1).

Leão XIII já havia admitido, conforme antes assinalado, que em casos de extrema necessidade o dever de socorrer os pobres com o supérfluo não fica restrito ao âmbito da caridade mas é uma exigência da justiça (RN 12), o que afeta o direito mesmo de propriedade e não apenas o seu uso.

\section{A questão da propriedade privada de Pio XII a Bento XVI}

Do Papa Pio XII em diante a Doutrina Social da Igreja acentuará cada vez mais o caráter social da propriedade privada e sua subordinação ao princípio da Destinação Universal dos Bens. Pio XII, embora não tenha promulgado nenhuma Encíclica Social em termos estritos, escreveu em sua Encíclica Sertum Laetitae (1939) que "Ponto fundamental da questão [social] é que os bens por Deus criados para todos os homens devem igualmente favorecer a todos, segundo os princípios da justiça e da caridade" (SL 14) ${ }^{14}$, aludindo claramente a este princípio, e colocando-o em relação não apenas com a caridade mas também com a justiça.

Posteriormente, na Rádio Mensagem da Solenidade de Pentecostes de $1941^{15}$, celebrando os 50 anos da Rerum Novarum, afirmará:

A encíclica Rerum Novarum expõe sobre a propriedade e sobre o sustento do homem princípios que com o tempo nada perderam do seu valor congênito e hoje, à distância de cinquenta anos, conservam ainda e jorram vivificante a sua íntima fecundidade. Nós próprio, na encíclica Sertum Laetitiae, endereçada aos Bispos dos Estados Unidos da América do Norte, chamamos a atenção de todos sobre o seu ponto fundamental, que afirma, como dissemos, a exigência incontestável de que os bens

14 Disponível em: http://www.vatican.va/content/pius-xii/pt/encyclicals/documents/hf_p-xii_enc_01111939_sertum-laetitiae.html. Acesso em: 20 fev. 2021.

15 Disponível em: http://www.vatican.va/content/pius-xii/pt/speeches/1941/documents/ hf_p-xii_spe_19410601_radiomessage-pentecost.html. Acesso em: 20 fev. 2021. 
criados por Deus para todos os homens, afluam a todos equitativamente, segundo os princípios da justiça e da caridade.

Com efeito, todo homem, como vivente dotado de razão, recebeu da natureza o direito fundamental de usar dos bens materiais da terra, embora se deixe à vontade humana, às formas jurídicas dos povos o regular mais particularmente a sua prática atuação. Este direito individual não pode de modo nenhum ser suprimido, nem sequer por outros direitos certos e pacíficos sobre bens materiais. Sem dúvida a ordem natural, que tem em Deus a sua origem, requer também a propriedade particular e a liberdade das transações comerciais como também a função reguladora do poder público sobre estas duas instituições. Tudo isto contudo fica subordinado ao fim natural dos bens materiais, nem pode prescindir do primeiro e fundamental direito, que a todos concede o seu uso; mas antes deve servir a tornar possível a sua atuação em conformidade com o seu fim. Só assim se poderá e deverá conseguir que a propriedade e o uso dos bens materiais deem à sociedade paz fecunda e consistência vital, e não constituam circunstâncias precárias, causadoras de lutas e invejas, quando abandonadas ao jogo desapiedado da força e da fraqueza. (Rádio Mensagem, n. 12 e 13).

João XXIII em sua primeira Encíclica Social, Mater et Magistra $(1961)^{16}$, ao aludir a esta Radio Mensagem afirma ${ }^{17}$ :

Quanto ao uso dos bens materiais, o nosso predecessor afirma que o direito de todo homem a usar daqueles bens para o seu próprio sustento tem prioridade sobre qualquer outro direito de natureza econômica, $e$ mesmo sobre o direito de propriedade. Certamente, acrescenta o nosso predecessor, também o direito de propriedade dos bens é um direito natural; mas, segundo a ordem objetiva estabelecida por Deus, o direito de propriedade é limitado, pois não pode constituir obstáculo a que seja satisfeita a "exigência irrevogável dos bens, criados por Deus para todos os homens, estarem equitativamente à disposição de todos, segundo os princípios da justiça e da caridade”. (MM 43).

Aqui é afirmado claramente que o direito de propriedade (privada), embora reconhecido como um direito natural é limitado, permanecendo subordinado ao princípio maior ao qual deve servir que é o princípio

16 Disponível em: http://www.vatican.va/content/john-xxiii/pt/encyclicals/documents/hf_j-xxiii_enc_15051961_mater.html. Acesso em: 20 fev. 2021.

$17 \mathrm{MICH}$, Marvin L. Mater et Magistra, Kenneth Himes (ed.), Modern Catholic Social Teaching. Commentaries and Interpretations. 2nd Edition. Washington DC: Georgetown University Press, 2018. p. 199-225. 
da Destinação Universal dos Bens. Na mesma Encíclica, João XXIII escreve sobre os processos de Socialização da Economia e faz um julgamento positivo sobre tal processo (MM 59-67), desde que este siga certos princípios:

Para o conseguir, requer-se, porém, que as autoridades públicas se tenham formado, e realizem praticamente, uma concepção exata do bem comum; este compreende o conjunto das condições sociais que permitem e favorecem nos homens o desenvolvimento integral da personalidade. E cremos necessário, além disso, que os corpos intermediários e as diversas iniciativas sociais, em que sobretudo procura exprimir-se e realizar-se a socialização, gozem de uma autonomia efetiva relativamente aos poderes públicos, e vão no sentido dos seus interesses específicos, com espirito de leal colaboração mútua e de subordinação às exigências do bem comum. Nem é menos necessário que os ditos corpos apresentem forma e substância de verdadeiras comunidades; isto é, que os seus membros sejam considerados e tratados como pessoas, e estimulados a participar ativamente na vida associativa". (MM 65).

Neste caso a Socialização é reconhecida como um bem:

Se a socialização se praticasse em conformidade com as leis morais indicadas, não traria, por sua natureza, perigos graves de vir a oprimir os indivíduos. Pelo contrário, ajudaria a que nestes se desenvolvessem as qualidades próprias da pessoa humana. Reorganizaria até a vida comum, tal como a apresentava o nosso predecessor Pio XI na encíclica Quadragesimo Anno: condição indispensável para a satisfação das exigências da justiça social. (MM 67).

Com ainda maior ênfase que nas Encíclicas anteriores, João XXIII afirma na Mater et Magistra a relação entre a liberdade dos indivíduos frente ao Estado e a propriedade privada:

Essa dúvida não tem razão de ser. O direito de propriedade privada, mesmo sobre bens produtivos, tem valor permanente, pela simples razão de ser um direito natural fundado sobre a prioridade ontológica e finalista de cada ser humano em relação à sociedade. Seria, aliás, inútil insistir na livre iniciativa pessoal em campo economico se a essa iniciativa não fosse permitido dispor livremente dos meios indispensáveis para se afirmar. Além disso, a história e a experiência provam que, nos regimes políticos que não reconhecem o direito de propriedade privada sobre os bens produtivos, são oprimidas ou sufocadas as expressões fundamentais 
da liberdade; é legítimo, portanto, concluir que estas encontram naquele direito garantia e incentivo. (MM 109).

Quer dizer, pretende que a propriedade privada seja garantia da liberdade essencial da pessoa humana e elemento insubstituível da ordem social. (MM 11)

Para isto, afirma também que: "Não basta afirmar que o caráter natural do direito de propriedade privada se aplica também aos bens produtivos; é necessário ainda insistir para que ela se difunda efetivamente entre todas as classes sociais" (MM 113).

Para João XXIII a propriedade privada, para efetivamente cumprir com sua função social, deve ser expandida e acessível a todos os cidadãos. A mesma posição é reafirmada em sua segunda Encíclica social, Pacem in Terris $(1963)^{18}$. (PT 21-22)

Coube a Paulo VI usar na sua primeira Encíclica social, Populorum Progressio (1967) ${ }^{19}$ a expressão "Destino Universal dos Bens" na abertura da terceira parte ${ }^{20}$, consagrando claramente o princípio patrístico, que, embora já estivesse presente na moderna Doutrina Social da Igreja desde Leão XIII, agora é enunciado com novo vigor, sobretudo quando antes de tratar do direito à propriedade privada, é afirmado o princípio da Destinação Universal dos Bens ${ }^{21}$ :

Enchei a terra e dominai-a: logo desde a primeira página, a Bíblia ensina-nos que toda a criação é para o homem, com a condição de ele aplicar o seu esforço inteligente em valorizá-la e, pelo seu trabalho, por assim dizer, completá-la em seu serviço. Se a terra é feita para fornecer a cada um os meios de subsistência e os instrumentos do progresso, todo o homem tem direito, portanto, de nela encontrar o que lhe é necessário. O recente Concilio lembrou-o: "Deus destinou a terra e tudo o que nela existe ao uso de todos os homens e de todos os povos, de modo que os

18 CHRISTIANSEN, Drew. Pacen in Terris em Kenneth Himes (ed.), Modern Catholic Social Teaching. Comentaries and Interpretations. 2nd Edition. Washington DC: Georgetown University Press, 2018. p. 226-254.

19 Disponível em: http://www.vatican.va/content/paul-vi/pt/encyclicals/documents/hf_p-vi_enc_26031967_populorum.html. Acesso em 21 fev. 2021.

20 FIGUEROA, Allan. Populorum Progressio, em Kenneth Himes (ed.), Modern Catholic Social Teaching. Commentaries and Interpretations. 2nd Edition. Washington DC: Georgetown University Press, 2018. p. 302-325.

21 ANTONCICH, Ricardo. Los Cristianos ante la Injusticia. Hacia uma lectura latino-americana de la doctrina social de la Iglesia. Bogotá: Grupo Social, 1980. p. 116-163. 
bens da criação afluam com equidade às mãos de todos, segundo a regra da justiça, inseparável da caridade”. Todos os outros direitos, quaisquer que sejam, incluindo os de propriedade e de comércio livre, estão-lhe subordinados: não devem portanto impedir, mas, pelo contrário, facilitar a sua realização; e é um dever social grave e urgente conduzi-los à sua finalidade primeira. (PP 22).

\section{Afirma ainda:}

Se alguém, gozando dos bens deste mundo, vir o seu irmão em necessidade e lhe fechar as entranhas, como permanece nele a caridade de Deus?".[21] Sabe-se com que insistência os Padres da Igreja determinaram qual deve ser a atitude daqueles que possuem em relação aos que estão em necessidade: "não dás da tua fortuna, assim afirma santo Ambrósio, ao seres generoso para com o pobre, tu dás daquilo que lhe pertence. Porque aquilo que te atribuis a ti, foi dado em comum para uso de todos. A terra foi dada a todos e não apenas aos ricos". Quer dizer que a propriedade privada não constitui para ninguém um direito incondicional e absoluto. Ninguém tem direito de reservar para seu uso exclusivo aquilo que é supérfluo, quando a outros falta o necessário. Numa palavra, "o direito de propriedade nunca deve exercer-se em detrimento do bem comum, segundo a doutrina tradicional dos Padres da Igreja e dos grandes teólogos". Surgindo algum conflito "entre os direitos privados e adquiridos e as exigências comunitárias primordiais", é ao poder público que pertence «resolvê-lo, com a participação ativa das pessoas e dos grupos sociais.» (PP 23).

O Papa João Paulo II $^{22}$ prossegue na sua primeira Encíclica Social, Laborem Exercens (1981) ${ }^{23}$ na mesma estrada aberta por Paulo VI, acentuando o princípio da Destinação Universal dos Bens, claramente enunciado, e a subordinação a este princípio do direito de propriedade $\operatorname{privada}^{24}$ :

A tradição cristã nunca defendeu tal direito como algo absoluto e intocável; pelo contrário, sempre o entendeu no contexto mais vasto do direito comum de todos a utilizarem os bens da criação inteira: o direito

22 CURRAN, Charles. The Moral Theology of Pope John Paulo II. Washington DC: Georgetown University Press, p. 202-247.

23 Disponível em: http://www.vatican.va/content/john-paul-ii/pt/encyclicals/documents/ hf_jp-ii_enc_14091981_laborem-exercens.html. Acesso em: 21 fev. 2021.

24 LAMOUREUX, Patricia. Laborem Exercens em Kenneth Himes (ed.), Modern Catholic Social Teaching. Commentaries and Interpretations. 2nd Edition. Washington DC: Georgetown University Press, 2018. p. 405-419. 
à propriedade privada está subordinado ao direito ao uso comum, subordinado à destinação universal dos bens.

Por outras palavras, a propriedade, segundo o ensino da Igreja, nunca foi entendida de maneira a poder constituir um motivo de contraste social no trabalho. Conforme já foi recordado acima, a propriedade adquire-se primeiro que tudo pelo trabalho e para servir ao trabalho. E isto diz respeito de modo particular à propriedade dos meios de produção. Considerá-los isoladamente, como um conjunto à parte de propriedades, com o fim de os contrapor, sob a forma do «capital», ao «trabalho»e, mais ainda, com o fim de explorar o trabalho, é contrário à própria natureza de tais meios e à da sua posse. Estes não podem ser possuídos contra o trabalho, como não podem ser possuídos para possuir, porque o único título legítimo para a sua posse - e isto tanto sob a forma da propriedade privada como sob a forma da propriedade pública ou coletiva -é que eles sirvam ao trabalho; e que, consequentemente, servindo ao trabalho, tornem possível a realização do primeiro princípio desta ordem, que é a destinação universal dos bens e o direito ao seu uso comum. Sob este ponto de vista, em consideração do trabalho humano e do acesso comum aos bens destinados ao homem, é também para não excluir a socialização, dando-se as condições oportunas, de certos meios de produção. No espaço dos decênios que nos separam da publicação da Encíclica Rerum Novarum, o ensino da Igreja tem vindo sempre a recordar todos estes princípios, remontando aos argumentos formulados numa tradição bem mais antiga, por exemplo aos conhecidos argumentos da Suma Teológica de Santo Tomás de Aquino. (LE 14).

Em sua Segunda Encíclica Social, Sollicitudo Rei Socialis $(1987)^{25}$, o Papa João Paulo II faz a recepção do princípio da Opção ou Amor Preferencial pelos Pobres, desenvolvido no âmbito da Igreja Latino Americana (SRS 42) ${ }^{26}$. Neste contexto volta a ressaltar o princípio da Destinação Universal dos Bens e afirma:

É necessário recordar mais uma vez o princípio típico da doutrina social cristã: os bens deste mundo são originariamente destinados a todos. $O$ direito à propriedade privada é válido e necessário, mas não anula o valor de tal princípio. Sobre a propriedade, de facto, grava «uma hipoteca social», quer dizer, nela é reconhecida, como qualidade intrínseca,

25 Disponível em: http://www.vatican.va/content/john-paul-ii/pt/encyclicals/documents/ hf_jp-ii_enc_30121987_sollicitudo-rei-socialis.html. Acesso em: 21 fev. 2021, 12:50.

26 CURRAN, Charles; HIMES, Kenneth; SHANNON, Thomas. Sollicitudo Rei Socialis em Kenneth Himes (ed.), Modern Catholic Social Teaching. Commentaries and Interpretations. 2nd Edition. Washington DC: Georgetown University Press, 2018. p. 429-449. 
uma função social, fundada e justificada precisamente pelo princípio da destinação universal dos bens. (SRS 42).

Na sua terceira Encíclica Social, Centesimus Annus (1991) ${ }^{27}$, o Papa João Paulo II reafirma o princípio da Destinação Universal dos Bens, e sublinha a subordinação do direito à propriedade privada a este princípio, afirmando que desde o início da Moderna Doutrina Social da Igreja isto é assim ensinado (CA 30-31).

O Papa Bento XVI em sua Encíclica Social Caritas in Veritate (2009), reafirma os princípios fundamentais da Doutrina Social da Igreja sem abordar diretamente a questão da Propriedade Privada ${ }^{28}$.

\section{O Papa Francisco e a questão da propriedade}

Desde o início o pontifício do Papa Francisco tem sido marcado pela ênfase na misericórdia e nas questões sociais e ambientais. O Papa Francisco em seu Magistério recepciona em profundidade a perspectiva latino-americana da Opção pelos Pobres, acolhendo seus dois significados centrais: assumir o lugar social dos pobres e permitir que este se torne sujeito eclesial e político-social. Entre os novos ensinamentos que traz na Doutrina Social da Igreja encontra-se, além da Opção pelos Pobres, uma visão estrutural da sociedade, compreendendo que a economia e a sociedade são configuradas por relações objetivas de caráter estruturais e não apenas intersubjetivas, que necessitam ser profundamente alteradas e pela denúncia de que vivemos uma profunda crise socioambiental que tem sua raiz em um sistema econômico concreto que produz morte e destruição.

A questão da Destinação Universal dos Bens encontra-se já presente em sua primeira exortação apostólica, Evangelii Gaudium (2013) ${ }^{29}$ :

A solidariedade é uma reação espontânea de quem reconhece a função social da propriedade e o destino universal dos bens como realidades

$27 \quad$ FINN, Daniel. Centesimus Annus, em Kenneth Himes (ed), Modern Catholic Social Teaching. Commentaries and Interpretations. 2nd Edition. Washington DC: Georgetown University Press, 2018. p. 450-481.

28 CLARK, Megan J. Caritas in Veritate em Kenneth Himes (ed), Modern Catholic Social Teaching. Commentaries and Interpretations. 2nd Edition. Washington DC: Georgetown University Press, 2018. p. 482-514.

29 Disponível em: http://www.vatican.va/content/francesco/pt/apost_exhortations/documents/papa-francesco_esortazione-ap_20131124_evangelii-gaudium.html\#Unidos_a_ Deus,_ouvimos_um_clamor. Acesso em: 23 fev. 2021, 11:00. 
anteriores à propriedade privada. A posse privada dos bens justifica-se para cuidar deles e aumentá-los de modo a servirem melhor o bem comum, pelo que a solidariedade deve ser vivida como a decisão de devolver ao pobre o que lhe corresponde. Estas convicções e práticas de solidariedade, quando se fazem carne, abrem caminho a outras transformações estruturais e tornam-nas possíveis. Uma mudança nas estruturas, sem se gerar novas conviç̧ões e atitudes, fará com que essas mesmas estruturas, mais cedo ou mais tarde, se tornem corruptas, pesadas e ineficazes. (EG 189).

Nesta afirmação de Francisco aparecem os três elementos básicos da Tradição Católica sobre a Propriedade: os bens foram criados para satisfazer as necessidades de todos (Destino Universal dos Bens), sendo que esta realidade é anterior à instituição da propriedade privada; a propriedade privada só se justifica se for para cuidar dos bens e multiplicá-los a serviço do bem comum; o supérfluo por direito é do pobre, ou seja, a solidariedade não é a tradução de um ato de generosidade mas de uma decisão de devolver ao pobre o que lhe corresponde.

Na sua primeira Encíclica Social, Laudato Si $(2015)^{30}$, o princípio da Destinação Universal dos Bens é tratado em toda uma seção (Cap II,6: 93-95)31. Ali Francisco afirma:

Hoje, crentes e não-crentes estão de acordo que a terra é, essencialmente, uma herança comum, cujos frutos devem beneficiar a todos. Para os crentes, isto torna-se uma questão de fidelidade ao Criador, porque Deus criou o mundo para todos. Por conseguinte, toda a abordagem ecológica deve integrar uma perspectiva social que tenha em conta os direitos fundamentais dos mais desfavorecidos. O princípio da subordinação da propriedade privada ao destino universal dos bens e, consequentemente, o direito universal ao seu uso é uma "regra de ouro» do comportamento social e o «primeiro princípio de toda a ordem ético-social». A tradição cristã nunca reconheceu como absoluto ou intocável o direito à propriedade privada, e salientou a função social de qualquer forma de propriedade privada. São João Paulo II lembrou esta doutrina, com grande ênfase, dizendo que «Deus deu a terra a todo o gênero humano, para que ela sustente todos os seus membros, sem excluir nem privilegiar ninguém». (LS 93).

30 Disponível em: http://www.vatican.va/content/francesco/pt/encyclicals/documents/ papa-francesco_20150524_enciclica-laudato-si.html. Acesso em: 23 fev. 2021, 12:00.

31 CZERNY, Michael; HAGENKORD, Bernd; SPADARO, Antonio. "Custodire L'Interra Creazione". Um servizio del Vescovo di Roma, em Francesco, Laudato Sí, Testo Integrale e Commento de "La Cilvità Cattolica. Milão: Ancora, 2015, p.137-152. 
A questão ecológica é colocada em relação ao princípio da Destinação Universal dos Bens:

O meio ambiente é um bem coletivo, patrimônio de toda a humanidade e responsabilidade de todos. Quem possui uma parte é apenas para a administrar em beneficio de todos. Se não o fizermos, carregamos na consciência o peso de negar a existência aos outros. Por isso, os bispos da Nova Zelândia perguntavam-se que significado possa ter o mandamento «não matarás», quando «uns vinte por cento da população mundial consomem recursos numa medida tal que roubam às nações pobres, eàs gerações futuras, aquilo de que necessitam para sobreviver». (LS 95).

A destruição ecológica e o uso irresponsável dos bens negam a existência aos outros, de modo especial negam aos mais pobres o necessário à vida, assim como roubam também das gerações futuras o necessário à própria existência. Para Francisco o princípio da Destinação Universal dos Bens compreende não apenas o dever de garantir a todos os que existem nesta geração o necessário, mas também de garantir que as gerações futuras possam ter acesso aos bens criados, pois estes foram feitos não apenas para satisfazer as necessidades dos que hoje vivem mas também para garantir a existência dos que ainda virão a existir. No Magistério do Papa Francisco o princípio da Destinação Universal dos Bens, além de sua dimensão social, ganha também uma dimensão ecológica e intergeracional.

Esta perspectiva é retomada pelo Papa Francisco em sua segunda Encíclica social, Frateli Tutti (2020) ${ }^{32}$, na qual, no Capítulo III, dedica toda uma seção (n. 118-120) ao tema "Repropor a função Social da Propriedade". Afirma o Papa Francisco:

O mundo existe para todos, porque todos nós, seres humanos, nascemos nesta terra com a mesma dignidade. As diferenças de cor, religião, capacidade, local de nascimento, lugar de residência e muitas outras não podem antepor-se nem ser usadas para justificar privilégios de alguns em detrimento dos direitos de todos. Por conseguinte, como comunidade, temos o dever de garantir que cada pessoa viva com dignidade e disponha de adequadas oportunidades para o seu desenvolvimento integral. (FT 118).

32 Disponível em: http://www.vatican.va/content/francesco/pt/encyclicals/documents/ papa-francesco_20201003_enciclica-fratelli-tutti.html. Acesso em: 23 fev. 2021. 
Depois de rememorar o princípio patrístico de que o supérfluo por direito é do pobre, citando São João Crisóstomo e São Gregório Magno, recorda também os ensinamentos de São João Paulo II e São Paulo VI sobre a função social da propriedade (FT120). Afirma ainda o Papa Francisco:

O direito à propriedade privada só pode ser considerado como um direito natural secundário e derivado do princípio do destino universal dos bens criados, e isto tem consequências muito concretas que se devem refletir no funcionamento da sociedade. Mas acontece muitas vezes que os direitos secundários se sobrepõem aos prioritários e primordiais, deixando-os sem relevância prática. (FT 120).

Entre as consequências práticas que o Papa Francisco tira deste princípio, está em sublinhar também sua dimensão internacional como já havia feito Paulo VI na Encíclica Populorum Progressio. O direito aos bens criados se estende a todos os povos e não possui fronteiras. Um povo ou país não pode se apropriar de modo exclusivo dos bens que encerra em suas fronteiras e utilizá-los de modo irresponsável ou usá-los contra os outros povos, condenando-os à miséria. Esta dimensão internacional, mundial, se torna ainda mais relevante em nossos dias devido ao problema ecológico que afeta a própria possibilidade de existência futura da humanidade, ao endividamento das Nações, ao comércio internacional injusto e à escassez de recursos em certas regiões que força a emigração (FT 121-127).

Na Audiência Geral de Quarta Feira, de 26 de agosto de 2020, em meio à Pandemia devido ao Coronavirus, o Papa Francisco pronunciou sua quarta catequese intitulada "Curar o Mundo", tratando nela do tema "O Destino Universal dos Bens e a Virtude da Esperança" ${ }^{33}$. Nela o Papa Francisco afirma:

Estes sintomas de desigualdade revelam uma doença social; é um vírus que provém de uma economia doente. Devemos simplesmente dizê-lo: a economia está doente. Adoeceu. É o resultado de um crescimento econômico iníquo - esta é a doença: o fruto de um crescimento econômico iníquo - que prescinde dos valores humanos fundamentais. No mundo de hoje, muito poucas pessoas ricas possuem mais do que o resto da humanidade. Repito isto porque nos fará refletir: poucos riquíssimos, um pequeno grupo, possui mais que o resto da humanidade. Esta é mera

33 Disponível em: http://www.vatican.va/content/francesco/pt/audiences/2020/documents/ papa-francesco_20200826_udienza-generale.html. Acesso em: 23 fev. 2021. 
estatística. É uma injustiça que clama aos céus! Ao mesmo tempo, este modelo econômico é indiferente aos danos infligidos à casa comum. Não cuida da casa comum. Estamos quase a superar muitos dos limites do nosso maravilhoso planeta, com consequências graves e irreversíveis: desde a perda de biodiversidade e alterações climáticas ao aumento do nível dos mares e à destruição das florestas tropicais. A desigualdade social e a degradação ambiental andam de mãos dadas e têm a mesma raiz (cf. Enc. Laudato si', 101): a do pecado de querer possuir, de querer dominar os irmãos e irmãs, de pretender possuir e dominar a natureza e o próprio Deus. Mas este não é o desígnio da criação. (\#3).

E também: A «subordinação da propriedade privada ao destino universal dos bens [...] é uma "regra de ouro" do comportamento social, e o primeiro princípio de toda a ordem ético-social» (LS, 93; [cf. São João Paulo II, Carta enc. Laborem Exercens, 19]). (\#8)

Este princípio articulado ao princípio da Opção Preferencial pelos Pobres, tratado pelo Papa na Catequese Curar o Mundo 3,34 de 19 de agosto de 2020, fez com que ele afirmasse na ocasião:

Estamos todos preocupados com as consequências sociais da pandemia. Todos. Muitos querem regressar à normalidade e retomar as atividades econômicas. É claro, mas esta "normalidade" não deve incluir injustiça social e degradação ambiental. A pandemia é uma crise e não se sai iguais de uma crise: ou saímos melhores ou saímos piores. Nós deveríamos sair melhores, para resolver as injustiças sociais e a degradação ambiental. Hoje temos uma oportunidade de construir algo diferente. Por exemplo, podemos fazer crescer uma economia de desenvolvimento integral dos pobres e não de assistencialismo. Com isto não pretendo condenar a assistência, as obras de assistência são importantes. Pensemos no voluntariado, que é uma das estruturas mais bonitas que a Igreja italiana possui. Mas devemos ir além e resolver os problemas que nos estimulam a fazer assistência. Uma economia que não recorra a remédios que na realidade envenenam a sociedade, tais como rendimentos dissociados da criação de empregos dignos (cf. EG, 204). Este tipo de lucro é dissociado da economia real, aquela que deveria beneficiar as pessoas comuns (cf. Enc. Laudato si' [LS], 109), e é também por vezes indiferente aos danos infligidos à casa comum. A opção preferencial pelos pobres, esta necessidade ética e social que vem do amor de Deus (cf. LS, 158), dá-nos o estímulo para pensar e conceber uma economia onde as pessoas, especialmente as mais pobres, estejam no centro. E

34 Disponível em: http://www.vatican.va/content/francesco/pt/audiences/2020/documents/ papa-francesco_20200819_udienza-generale.html. Acesso em: 23 fev. 2021. 
também nos encoraja a projetar o tratamento do vírus, privilegiando quem tem mais necessidade. Seria triste se na vacina contra a Covid-19 fosse dada a prioridade aos mais ricos! Seria triste se esta vacina se tornasse propriedade desta ou daquela nação e não fosse universal e para todos. E que escândalo seria se toda a assistência económica que estamos a observar - a maior parte dela com dinheiro público - se concentrasse no resgate das indústrias que não contribuem para a inclusão dos excluídos, para a promoção dos últimos, para o bem comum ou para o cuidado da criação. (\#6).

Nestas Catequeses encontram-se os elementos centrais do Magistério Social do Papa Francisco. Vivemos uma profunda crise socioambiental que é agravada drasticamente pela pandemia do Coronavírus. Diante desta crise somos mais uma vez interpelados a mudar profundamente a economia, para que o princípio da Destinação Universal dos Bens se torne realmente efetivo. Como consequência imediata o Papa apresenta sua preocupação com os pobres no contexto da Pandemia, afirmando que estes devem ter prioridade e a eles deve ser garantido o necessário à vida, inclusive o acesso às vacinas.

No final de novembro de 2020 o Papa Francisco pronunciou uma mensagem em vídeo destinada ao encontro virtual dos juízes, membros dos comitês para os direitos sociais, da África e da América $(30 / 11 / 2020)^{35}$. Nesta mensagem o Papa Francisco aborda com ênfase a questão da justiça social e conclama aos juízes a se colocarem no meio do povo e não acima deste:

Eé muito difícil poder construir a justiça social, sem se basear no povo. Ou seja, a história leva-nos ao povo, aos povos. Será uma tarefa muito mais fácil, se introduzirmos o desejo livre, puro e simples de ser povo, sem pretender ser elite iluminada, mas sim povo, mostrando-nos constantes e incansáveis no trabalho de incluir, integrar e erguer quantos caíram. O povo é a quinta base para a construção da justiça social. E, a partir do Evangelho, o que Deus nos pede, a nós crentes, é que sejamos povo de Deus, não elite de Deus. Pois aqueles que seguem o caminho da "elite de Deus" acabam nos conhecidos clericalismos elitistas que, em geral, trabalham pelo povo, mas nada fazem com o povo, não se sentem um povo. (\#8).

35 Disponível em: http://www.vatican.va/content/francesco/pt/messages/pont-messages/2020/documents/papa-francesco_20201130_videomessaggio-giudici-incontro. html. Acesso em: 23 fev. 2021. 
O papa afirma que para se fazer justiça social é necessário lutar contra as causas estruturais que produzem a pobreza:

Por fim, no momento de reconsiderar a ideia de justiça social, sugiro-vos que o façais demonstrando-vos solidários e justos. Solidários, lutando contra as causas estruturais da pobreza, da desigualdade, da falta de trabalho, de terra e de habitação. Terra, teto e trabalho, techo, tierra y trabajo, os três "Tês" que nos consagram dignos. Em síntese, lutando contra aqueles que negam os direitos sociais e laborais. Lutando contra a cultura que leva a usar os outros, a escravizar o próximo, e acaba por tirar a dignidade dos outros. Não vos esqueçais que, entendida no seu sentido mais profundo, a solidariedade é um modo de fazer história. (\#8).

E, neste sentido, em relação à Propriedade Privada o Papa Francisco recorda que:

Construamos a nova justiça social, admitindo que a tradição cristã nunca reconheceu como absoluto e intocável o direito à propriedade particular, realçando sempre a função social de cada uma das suas formas. (\#9).

$O$ direito à propriedade é um direito natural secundário, derivado do direito que todos têm, nascido do destino universal dos bens da criação. Não há justiça social que se possa consolidar sobre a iniquidade, que implique a concentração da riqueza. (\#11-12).

O conceito de justiça social para o Papa Francisco deve ser compreendido à luz dos princípios da Opção pelos Pobres e da Destinação Universal dos Bens ao quais está subordinado o princípio da propriedade privada.

\section{Conclusão}

O princípio do direito à Propriedade Privada no Papa Francisco é claramente relativizado e subordinado ao Princípio da Destinação Universal dos Bens. O seu ensinamento está em plena conformidade com o Ensino Social Patrístico, com a teologia escolástica e com o desenvolvimento do tema da Moderna Doutrina Social da Igreja que tem seu início com Leão XIII através da Encíclica Rerum Novarum (1891). Se nesta, inicialmente ressaltou-se o Direito à Propriedade Privada, devido ao contexto do socialismo nascente, em seguida e com cada vez maior ênfase se afirma através dos sucessivos Pontífices o princípio patrístico da Destinação Universal dos Bens e da subordinação a este princípio do direito de Propriedade Privada. 
No Papa Francisco encontramos novas ênfases, e a articulação do princípio da Destinação Universal dos Bens com a Opção Pelos Pobres. Na perspectiva do Papa Francisco, vivemos uma profunda crise socioambiental, que se deve à existência de um sistema econômico iníquo cujas estruturas produzem pobreza, desigualdade e destruição da natureza. Entre tais estruturas encontra-se uma concepção absoluta do direito à Propriedade Privada que permitiria a seus detentores usá-la mesmo contra uma parte da humanidade, os pobres e a natureza. O Papa Francisco afirma a prioridade da vida e do princípio da Destinação Universal dos Bens sobre a propriedade privada e o caráter social, ecológico e internacional deste princípio, assim como a prioridade dos pobres nos desígnios misericordiosos de Deus.

\section{Referências}

AMBROGIO. La storia di Naboth. Introduzione, commento, edizione critica, traduzione a cura di Maria Grazia Mara. L'Aquila: Japadre, 1975.

ANTONCICH, Ricardo. Los Cristianos ante la Injusticia. Hacia uma lectura latino-americana de la doctrina social de la Iglesia. Bogotá: Grupo Social, 1980.

CESAREIA, Basílio de. Homilia sobre Lucas 12. Homilia sobre a origem do homem. Tratado sobre o Espirito Santo. São Paulo: Paulus, 2014.

CHRISTIANSEN, Drew. Pacem in Terris em Kenneth Himes (ed.). Modern Catholic Social Teaching. Comentaries and Interpretations. 2nd Edition. Washington DC: Georgetown University Press, 2018.

CLARK, Megan J. Caritas in Veritate em Kenneth Himes (ed.). Modern Catholic Social Teaching. Commentaries and Interpretations. 2nd Edition. Washington DC: Georgetown University Press, 2018.

CURRAN, Charles. Catholic Social Teachimg. A Historical, Theological and Ethical Analysis. 1891-Present. Washington DC: Georgetown University Press, 2002.

CURRAN, Charles. The Moral Theology of Pope John Paulo II. Washington DC: Georgetown University Press.

CURRAN, Charles; HIMES, Kenneth; SHANNON, Shannon. Sollicitudo Rei Socialis em Kenneth Himes (ed.). Modern Catholic Social Teaching. Commentaries and Interpretations. 2nd Edition. Washington DC: Georgetown University Press, 2018. 
CZERNY, Michael; HAGENKORD, Bernd; SPADARO, Antonio. "Custodire L'Interra Creazione". Um servizio del Vescovo di Roma, em Francesco, Laudato Sí, Testo Integrale e Commento de "La Civiltà Cattolica, Milão: Ancora, 2015.

FIGUEROA, Allan. Populorum Progressio, em Kenneth Himes (ed.). Modern Catholic Social Teaching. Commentaries and Interpretations. 2nd Edition. Washington DC: Georgetown University Press, 2018.

FINN, Daniel. Centesimus Annus, em Kenneth Himes (ed.). Modern Catholic Social Teaching. Commentaries and Interpretations. 2nd Edition. Washington DC: Georgetown University Press, 2018.

HOLlAnd, J. Modern Catholic Social Teaching. The Popes confront the industrial age 1740-1958. New York: Paulist Press, 2003. Também de forma mais extensa desenvolvi o tema dos sucessivos paradigmas na Doutrina Social da Igreja de Leão XIII a Francisco em ANDRADE, P. Um Novo paradigma na Doutrina Social da Igreja, REB vol. 79, n. 314 (Set./Dez. 2019), p. 615-636.

LAMOUREUX, Patricia. Laborem Exercens em Kenneth Himes (ed.). Modern Catholic Social Teaching. Commentaries and Interpretations. 2nd Edition. Washington DC: Georgetown University Press, 2018.

MARA, Maria Grazia. Annuncio evangelico e istanze sociali nel IV secolo. Augustinianum, vol. 17, n. 1, p. 7-24.

MICH, Marvin L. Mater et Magistra, Kenneth Himes (ed.). Modern Catholic Social Teaching. Commentaries and Interpretations. 2nd Edition. Washington DC: Georgetown University Press, 2018.

OTERO, A. de Santos. Los Evangelios Apocrifos. Edición crítica y bilíngue. 6. ed. Madri: BAC, 1988. p. 42-43. Alguns autores consideram ser este um fragmento do chamado Evangelho dos Nazarenos, cf. CRAVERI, M. (org.). I Vangeli Apocrifi. 5. ed. Torino: Einaudi, 1969.

RESTITUTO SIERRA BRAVO. Doctrina Social y Economica de los Padres de La Iglesia. Coleccion General de Documentos y Textos. Madri: COMPI, 1967.

SHANNON, Thomas A. Rerum Novarum em Kenneth Himes (ed.). Modern Catholic Social Teaching. Commentaries and Interpretations. 2nd Edition. Washington DC: Georgetown University Press, 2018. 


\section{Documentos na Internet}

http://www.vatican.va/content/francesco/pt/apost_exhortations/documents/papa-francesco_esortazione-ap_20131124_evangelii-gaudium. html\#Unidos_a_Deus,_ouvimos_um_clamor.Acesso em: 23 fev. 2021, 11:00. http:/www.vatican.va/content/francesco/pt/audiences/2020/documents/ papa-francesco_20200819_udienza-generale.html. Acesso em: $23 \mathrm{fev}$. 2021, 10:52.

http:/www.vatican.va/content/francesco/pt/audiences/2020/documents/ papa-francesco_20200826_udienza-generale.html. Acesso em: 23 fev. 2021, 10:30.

http://www.vatican.va/content/francesco/pt/encyclicals/documents/ papa-francesco_20201003_enciclica-fratelli-tutti.html. Acesso em: 23 fev. 2021, 09:30.

http:/www.vatican.va/content/francesco/pt/encyclicals/documents/ papa-francesco_20150524_enciclica-laudato-si.html. Acesso em: 23 fev. 2021, 12:00.

http://www.vatican.va/content/francesco/pt/messages/pont-messages/2020/documents/papa-francesco_20201130_videomessaggio-giudici-incontro.html. Acesso em: 23 fev. 2021, 11:10.

http://www.vatican.va/content/john-paul-ii/pt/encyclicals/documents/ hf_jp-ii_enc_30121987_sollicitudo-rei-socialis.html. Acesso em: 21 fev. 2021, 12:50.

http://www.vatican.va/content/john-paul-ii/pt/encyclicals/documents/ hf_jp-ii_enc_14091981_laborem-exercens.html. Acesso em: 21 fev. 2021, $1 \overline{2}: 30$.

http://www.vatican.va/content/john-xxiii/pt/encyclicals/documents/ hf_j-xxiii_enc_15051961_mater.html. Acesso em: 20 fev. 2021, 14:00.

http://www.vatican.va/content/leo-xiii/pt/encyclicals/documents/hf_l-xiii_enc_15051891_rerum-novarum.html. Acesso em: 20 fev. 2021, 08:-̄30. http://www.vatican.va/content/paul-vi/pt/encyclicals/documents/hf_p-vi_enc_26031967_populorum.html. Acesso em: 21 fev. 2021, 11:00. https://sumateologica.files.wordpress.com/2017/04/suma-teolc3b3gica. pdf. Acesso em: 18 fev. 2021, 12:58. 